\title{
Demethylation of MAGE promoters during gastric cancer progression
}

\author{
T Honda ${ }^{1,2}$, G Tamura ${ }^{* 1}$, T Waki', S Kawata ${ }^{2}$, M Terashima ${ }^{3}$, S Nishizuka ${ }^{4}$ and T Motoyama' \\ 'Department of Pathology, Yamagata University School of Medicine, Yamagata, Japan; ${ }^{2}$ Department of Internal Medicine, Yamagata University School of \\ Medicine, Yamagata, Japan; ${ }^{3}$ Department of Surgery, Fukushima Medical University, Fukushima, Japan; ${ }^{4}$ Laboratory of Molecular Pharmacology, National \\ Cancer Institute, National Institutes of Health, Bethesda, MD, USA
}

Melanoma antigen (MAGE)-encoding genes are expressed in various tumour types via demethylation of their promoter CpG islands, which are silent in all non-neoplastic tissues except for the testis and placenta. The clinicopathological significance of demethylation of MAGE genes in gastric carcinoma is not known. We investigated the promoter methylation status of MAGE-A I and -A3 in 10 gastric cancer cell lines and in surgical specimens from 84 gastric cancer patients by methylation-specific PCR (MSP). Expression of MAGE-A I and $-A 3$ in the 10 gastric cancer cell lines was also investigated by RT-PCR. Any correlation between the methylation status of the MAGE promoters and clinicopathological characteristics of the gastric cancer patients was then assessed. Eight of the 10 gastric cancer cell lines showed demethylation of both MAGE-A I and -A3, and the remaining two cell lines did either of MAGE-A / or -A3. Expression of MAGE-AI and -A3 was confirmed in seven and nine of the 10 gastric cancer cell lines, respectively. The MAGE-AI and -A3 promoters were demethylated in 29\% (25 out of 84 ) and $66 \%$ (56 out of 84 ) of the gastric tumour specimens, respectively. Demethylation of both MAGE-AI and -A3 promoters $(n=22)$ was found more frequently in gastric cancer patients in advanced clinical stages $(P=0.0035)$, and these patients also exhibited a higher incidence of lymph node metastasis $(P=0.0007)$ compared to those patients without demethylation $(n=25)$. Furthermore, demethylation patients tended to have a worse prognosis, although this difference was not statistically significant $(P=0.183)$. Demethylation of MAGE-Al and $-A 3$ occurs during progressive stages of gastric cancer, and may be associated with aggressive biological behaviour of gastric cancer.

British Journal of Cancer (2004) 90, 838-843. doi: I0.1038/sj.bjc.660I600 www.bjcancer.com

(c) 2004 Cancer Research UK

Keywords: gastric cancer; MAGE; demethylation

Epigenetic alterations, including hypermethylation of promoter CpG islands and histone deacetylation of tumour suppressor and tumour-related genes (Choi et al, 2001; Jones and Takai, 2001; Kim et al, 2001; Goodman and Watson, 2002; Jones and Baylin, 2002) as well as global DNA hypomethylation (Eden et al, 2003; Gaudet et al, 2003; Lengauer, 2003), have been recognised as important contributors to carcinogenesis in humans. Global DNA hypomethylation has been observed in carcinomas of the breast, liver, and colon, and is considered to occur in the early stages of tumour development (Goelz et al, 1985; Cravo et al, 1996; Narayan et al, 1998; Lin et al, 2001; Bariol et al, 2003). However, little is known about promoter hypomethylation of specific genes such as oncogenes and growth-related genes, with the exception of the association between demethylation and increased expression of c-abl, c-myc, Ha-ras, and raf (Cheah et al, 1984; Weitzman et al, 1989; Sharrad et al, 1992; Counts and Goodman, 1994).

Human melanoma cells express antigens that are recognised by cytolytic T lymphocytes derived from the blood of tumour-bearing patients or from tumour-infiltrating lymphocytes (Boon et al, 1994). A number of such antigens are encoded by genes of the MAGE family (Van der Bruggen et al, 1991; Lucas et al, 2000). A

*Correspondence: Dr G Tamura;

E-mail: gtamura@med.id.yamagata-u.ac.jp

Received 10 July 2003; revised 21 October 2003; accepted 26 November 2003 total of 19 MAGE genes are located on chromosome X (Lucas et al, 2000), and are expressed in other tumours, including gastric cancer, in addition to melanoma (Van der Bruggen et al, 1991; Brasseur et al, 1992; Chambost et al, 1993; Inoue et al, 1995a, b; Gotoh et al, 1998; Takahashi et al, 1998). Although the functions of the various MAGE proteins remain to be elucidated, $M A G E$ gene expression is known to be activated by promoter demethylation in a similar manner as the oncogenes and growthrelated genes described above (De Smet et al, 1996). These genes are silent in normal tissues except for the testis and placenta (De Plaen et al, 1994; De Smet et al., 1994), and may be targets for future cancer immunotherapies (Marchand et al, 1999; Jang et al, 2001).

In the present study, we investigated the promoter methylation status of $M A G E-A 1$ and $-A 3$, which were the most frequent targets for immunotherapy, in gastric cancers, and analysed the correlation between the MAGE-A1 and $-A 3$ methylation status and clinicopathological parameters of gastric cancer patients, including event-free survival.

\section{MATERIALS AND METHODS}

\section{Gastric cancer cell lines}

We have investigated 10 gastric cancer cell lines with variable histologies that were cultured under appropriate conditions in our 
laboratory: MKN1, an adenosquamous cell carcinoma; MKN7, a well-differentiated adenocarcinoma; MKN28 and MKN74, moderately differentiated adenocarcinomas; MKN45 and KWS-I, poorly differentiated adenocarcinoma; KATO-III, a signet-ring cell carcinoma; TSG11, a hepatoid carcinoma; and ECC10 and ECC12, endocrine cell carcinomas.

\section{Primary gastric cancers}

In total, 84 pairs of cancerous and noncancerous gastric tissues (51 differentiated and 31 undifferentiated carcinomas; 25 early-stage carcinomas that demonstrated a depth of invasion limited to the submucosa and 57 advanced stage carcinomas) were surgically obtained from 84 gastric cancer patients. These tissues were immediately frozen and stored at $-80^{\circ} \mathrm{C}$ until analysis. All patients received a median of 36.7 months of follow-up care (range, 1-77 months). Signed informed consent was obtained from every patient to allow the use of biological materials for biological studies.

\section{DNA extraction}

DNA was extracted from 10 gastric carcinoma cell lines and 84 primary gastric cancers and their corresponding noncancerous gastric tissues with SepaGene (Sanko-Junyaku, Tokyo, Japan).

\section{RNA extraction}

Total RNA was isolated from 10 gastric carcinoma cell lines with the TRIZOL reagent (Gibco BRL, Life Technologies, Gaithersburg, $\mathrm{MD}, \mathrm{USA}$ ).

\section{Bisulphite modification and methylation-specific polymerase chain reaction (MSP)}

Treatment of DNA samples with sodium bisulphite converts all unmethylated cytosines to uracils and does not affect methylated cytosines. Briefly, $2 \mu \mathrm{g}$ of genomic DNA were denatured with sodium hydroxide and modified by sodium bisulphite. The samples were then purified using Wizard DNA purification resin (Promega, Madison, WI, USA), treated with $\mathrm{NaOH}$, recovered in ethanol, and resuspended in $30 \mu \mathrm{l}$ of distilled water. Amplification was achieved in a $20 \mu \mathrm{l}$ reaction volume containing $2 \mu \mathrm{l}$ of GeneAmp PCR Gold Buffer (PE Applied Biosystems, Foster City, CA, USA), $1.0 \mathrm{~mm} \mathrm{MgCl}_{2}, 1 \mu \mathrm{l}$ each primer, $0.2 \mathrm{~mm}$ dNTPs, and $1 \mathrm{U}$ Taq polymerase (AmpliTaq Gold DNA Polymerase, PE Applied Biosystems). After heating at $94^{\circ} \mathrm{C}$ for $10 \mathrm{~min}$, polymerase chain reaction (PCR) was performed in a thermal cycler (GeneAmp 2400, PE Applied Biosystems) for 35 cycles, each of which consisted of denaturation at $94^{\circ} \mathrm{C}$ for $30 \mathrm{~s}$, annealing at $54^{\circ} \mathrm{C}$ for $60 \mathrm{~s}$, and extension at $72^{\circ} \mathrm{C}$ for $60 \mathrm{~s}$, followed by a final 7-min extension at $72^{\circ} \mathrm{C}$. A positive control (Sss-I methylase-treated DNA) and negative control (distilled water without DNA) were included for each amplification. The PCR products were separated on a $6 \%$ nondenaturing polyacrylamide gel. The following primer sets were used: MG1 M forward ( $5^{\prime}$-ATT TAG GTA GGA TTC GGT TTT C- $3^{\prime}$ ) and MG1 M reverse ( $5^{\prime}$-AAA CTA AAA CGT CTT CCC GCG-3 ${ }^{\prime}$ ) for the methylated MAGE-A1 sequence; MG1U forward (5'-ATT TAG GTA GGA TTT GGT TTT T- $3^{\prime}$ ) and MG1U reverse (5'-AAA CTA AAA CAT CTT CCC ACA-3') for the MAGE-A1 unmethylated sequence; MG3 $M$ forward ( $5^{\prime}$-CGT TTT GAG TAA CGA GCG AC$\left.3^{\prime}\right)$ and MG3 M reverse (5'-ACT AAA ACG ACG AAA ATC GAC G$\left.3^{\prime}\right)$ for the MAGE-A3 methylated sequence; MG3U forward (5'-TGT TTT GAG TAA TGA GTG AT- $3^{\prime}$ ) and MG3U reverse ( $5^{\prime}$-ACT AAA ACA ACA AAA ATC AAC A-3') for the MAGE-A3 unmethylated sequence. Methylated and unmethylated PCR products of MAGE$A 1$ and $-A 3$ in gastric cancer cell lines were sequenced. The PCR products were purified using QIA Quick PCR Purification Kit (QIAGEN, Tokyo). The purified PCR products were sequenced with the BigDye Terminator Cycle Sequencing Ready Reaction Kit (PE Applied Bioststems). Gel electrophotesis, data collection, and analysis were carried out with a Genetic Analyser (model 310, PE Applied Biosystems).

\section{Reverse transcription-PCR (RT - PCR)}

Isolated RNA was reverse-transcribed and amplified using a ONESTEP RT - PCR System (Gibco BRL). Primer sequences used were: MG1 forward ( $5^{\prime}$-TGT GGG CAG GAG CTG GGC AA-3') and MG1 reverse (5'-GCC GAA GGA ACC TGA CCC AG-3') for MAGE-A1; MG3 forward ( $5^{\prime}$-AAG CCG GCC CAG GCT CGG T-3') and MG3 reverse ( $5^{\prime}$-GCT GGG CAA TGG AGA CCC AC- $3^{\prime}$ ) for MAGE-A3; $\beta$-actin forward ( $5^{\prime}$-AAA TCT GGC ACC ACA CCT T- $\left.3^{\prime}\right)$ and $\beta$ actin reverse ( $5^{\prime}$-AGC ACT GTG TTG GCG TAG AG-3') for $\beta$-actin. Reverse transcription-PCR products were separated on $3 \%$ agarose gels.

\section{Preparation of positive control}

Sss-I methylase (New England BioLabs, Inc.,. Beverly, MA, USA) was used to methylate $100 \mu \mathrm{g}$ of peripheral blood DNA, which was modified by sodium bisulphite as described above.

\section{Statistical analysis}

Statistical comparisons were performed using Fisher's exact test. A $P<0.05$ was considered significant. Survival analysis was performed using a Kaplan-Meier curve with log rank test.

\section{RESULTS}

\section{Demethylation and expression of MAGE-A1 and -A3 in} gastric cancer cell lines

The demethylation status of MAGE-A1 and $-A 3$ was determined in nine of the 10 cell lines; it was not determined for MAGE-A1 in line MKN45 or for MAGE-A3 in line KWS-I (Figure 1). Both the methylated and demethylated alleles of $M A G E-A 1$ were present in KWS-I, and the methylated and demethylated alleles of MAGE-A3 were present in MKN1, MKN7, MKN28, MKN45, MKN74, KATOIII, and ECC10.

Expression of MAGE-A1 was confirmed in seven cell lines (MKN1, MKN7, MKN28, MKN74, KATO-III, TSG11, and ECC12), but not in the remaining three lines (MKN45, KWS-I, and ECC10), and expression of $M A G E-A 3$ was confirmed in all lines except KWS-I (Figure 2). We have confirmed the methylated or unmethylated status of each $M A G E$ promoter in all the gastric cancer cell lines by direct sequencing of MSP products (data not shown). Thus, promoter methylation of $M A G E-A 1$ and - $A 3$ directly correlates with their expression, except for $M A G E-A 1$ in line ECC10.

\section{Demethylation of $M A G E-A 1$ and $-A 3$ in primary gastric cancers and corresponding non-neoplastic gastric tissues}

Demethylation of MAGE-A1 and -A3 was detected in 29\% (25 out of 84 ) and $66 \%$ (56 out of 84 ) of gastric cancer samples and in $0 \%$ ( 0 out of 84 ) and 7\% (6 out of 84 ) of their corresponding nonneoplastic gastric tissues, respectively (Figure 3 ). Demethylation of both MAGE-A1 and $-A 3$ was detected in $26 \%$ (22 out of 84 ) of the samples and of either of the genes in $44 \%$ (37 out of 84 ). In the remaining samples $(29 \%, 25$ out of 84$)$, both promoters remained methylated. 


\section{Correlation between demethylation of MAGE promoters and clinicopathological parameters}

Gastric cancer patients who exhibited demethylation of both the $M A G E-A 1$ and $-A 3$ promoters $(n=22)$ were at a more advanced clinical stage $(P=0.0035)$. and had a higher incidence of lymph node metastasis $(P=0.0007)$ compared with those who did not

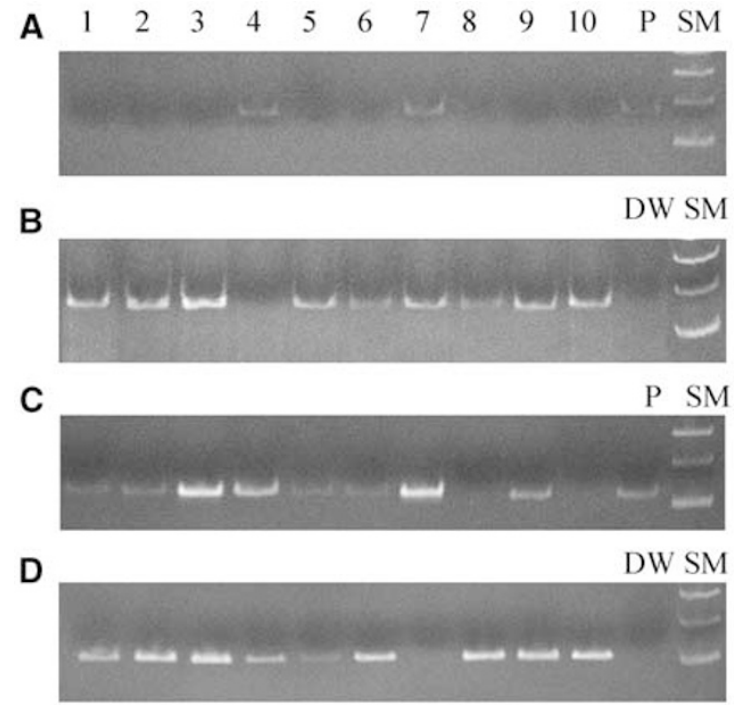

Figure I Methylation-specific PCR of gastric cancer cell lines. (A) Methylated-sequence-specific PCR of MAGE-Al; (B) Unmethylatedsequence-specific PCR of MAGE-Al; (C) Methylated-sequence-specific PCR of MAGE-A3; (D) Unmethylated-sequence-specific PCR of MAGE-A3; $P$, positive control; DW, distilled water; SM, size marker. Methylated MAGE$A l$ is present in lanes 4 and $7(\mathbf{A})$, and demethylated MAGE-Al is present in all lanes except lane 4 (B). Methylated MAGE-A3 is present in lanes I-7 and $9(\mathbf{C})$, and demethylated MAGE-A3 is present in all lanes except lane 7 (D). Lanes: I, MKNI; 2, MKN7; 3, MKN28; 4, MKN45; 5, MKN74; 6, KATO-III; 7, KWS-I; 8, TSGII; 9, ECCI0; and I0, ECCI2.

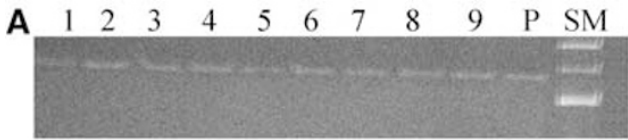

B

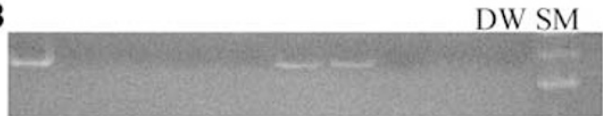

C

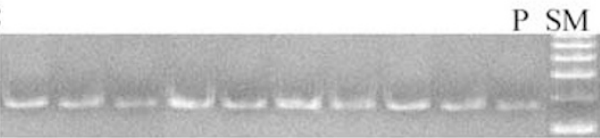

D

DW SM

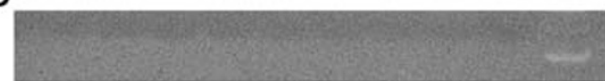

have demethylated MAGE-A1 and $-A 3$ promoters $(n=25)$ (Table 1). Furthermore, patients with demethylated MAGE-A1 and $-A 3$ promoters tended to have a worse prognosis, although this difference was not statistically significant by the log rank test $(P=0.183)$ (Figure 4). Patients with demethylation of only one of the two promoters exhibited biological features intermediate to those of the other two groups.

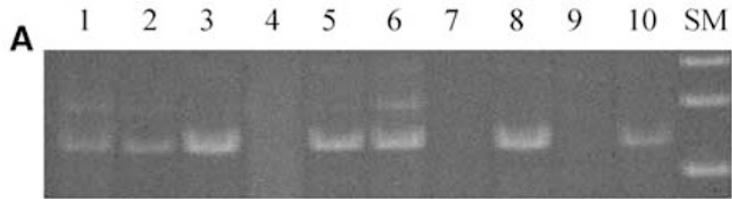

B

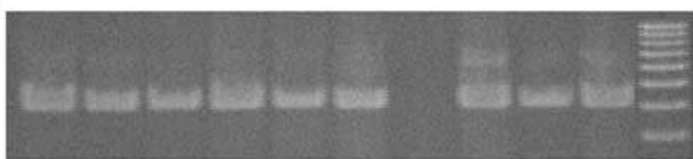

C

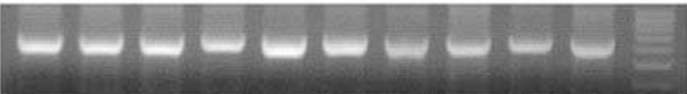

Figure 2 Reverse transcription-PCR of gastric cancer cell lines; $(\mathbf{A})$ RT-PCR of MAGE-A I; (B) RT-PCR of MAGE-3; (C) RT-PCR of $\beta$-actin; SM, size marker. MAGE-AI mRNA is not present in lanes 4, 7, or $9(\mathbf{A})$ MAGE-A3 mRNA is not present in lane 7 (B). $\beta$-actin serves as an internal control (C). Lanes: I, MKNI; 2, MKN7; 3, MKN28; 4, MKN45; 5, MKN74; 6, KATO-III; 7, KWS-I; 8, TSGII; 9, ECCI0; and I0, ECCI2.

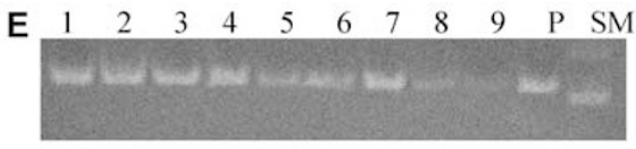

$\mathbf{F}$

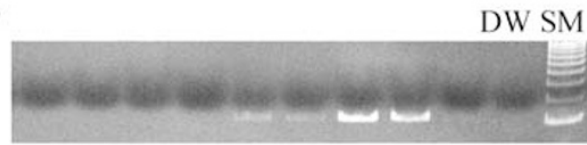

G

P SM

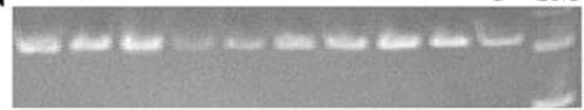

$\mathrm{H}$

DW SM

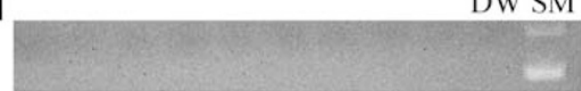

Figure 3 Methylation-specific PCR of primary gastric cancer specimens and their corresponding non-neoplastic gastric tissues; (A) methylated-sequencespecific PCR of MAGE-A I in gastric cancer specimens; (B) unmethylated-sequence-specific PCR of MAGE-A/ in gastric cancer specimens; (C) methylatedsequence-specific PCR of MAGE-AI in non-neoplastic gastric tissues; (D) unmethylated-sequence-specific PCR of MAGE-A I in non-neoplastic gastric tissues; (E) methylated-sequence-specific PCR of MAGE-A3 in gastric cancer specimens; $(\mathbf{F})$ unmethylated-sequence-specific PCR of MAGE-A3 in gastric cancer specimens; (G) methylated-sequence-specific PCR of MAGE-A3 in non-neoplastic gastric tissues; $(\mathbf{H})$ unmethylated-sequence-specific PCR of MAGE-A3 in non-neoplastic gastric tissues; P, positive control; DW, distilled water; SM, size marker. Methylated MAGE-A/ and -A3 is present in all lanes (A, C, E, and $\mathbf{G}$ ). In gastric cancer specimens, demethyled MAGE-AI and -A3 are present in lanes I, 6, and 7 of $(\mathbf{B})$ and in lanes 5-8 of (F), respectively, whereas none of the non-neoplastic gastric tissues exhibit demethylation of MAGE-A I or -A3 (D and H). Lanes: I, M244; 2, M245; 3, M246; 4, M248; 5, M25I; 6, M254; 7, M256; 8, M257; and 9, M262. 
Table I Correlation of MAGE promoter methylation status and clinicopathological characteristics in gastric cancer patients

\begin{tabular}{|c|c|c|c|c|c|}
\hline & \multicolumn{3}{|c|}{ Promoter methylation status } & \multicolumn{2}{|r|}{$P$-value } \\
\hline & $\begin{array}{c}\text { Not } \\
\text { altered }\end{array}$ & $\begin{array}{l}\text { One demethylated } \\
\text { promoter }\end{array}$ & $\begin{array}{c}\text { Two demethylated } \\
\text { promoters }\end{array}$ & $\begin{array}{l}\text { Not altered } \\
\text { vs rest }\end{array}$ & $\begin{array}{l}\text { Not altered vs two } \\
\text { demethylated promoters }\end{array}$ \\
\hline Number of patients & 25 & 37 & 22 & & \\
\hline Age (mean) (Years) & 66.8 & 64.6 & 69.1 & NS & NS \\
\hline Gender & & & & NS & NS \\
\hline$M$ & 20 & 25 & 19 & & \\
\hline $\mathrm{F}$ & 5 & 12 & 3 & & \\
\hline Unknown & 0 & 0 & 0 & & \\
\hline Stage & & & & 0.002 & 0.0035 \\
\hline Early & 15 & | | & 4 & & \\
\hline Advanced & 10 & 26 & 18 & & \\
\hline Unknown & 0 & 0 & 0 & & \\
\hline Histological differentiation & & & & NS & NS \\
\hline Differentiated & 16 & 24 & 12 & & \\
\hline Undifferentiated & 9 & 13 & 10 & & \\
\hline Unknown & 0 & 0 & 0 & & \\
\hline Location & & & & NS & NS \\
\hline Lower & 8 & 15 & 10 & & \\
\hline Middle & 10 & 15 & 5 & & \\
\hline Upper & 5 & 4 & 6 & & \\
\hline Unknown & 2 & 3 & 1 & & \\
\hline Lymph node metastasis & & & & 0.03 & 0.0007 \\
\hline Present & 7 & 21 & 17 & & \\
\hline Absent & 18 & 16 & 5 & & \\
\hline Unknown & 0 & 0 & 0 & & \\
\hline
\end{tabular}

NS = not significant by Fisher's exact probability test.

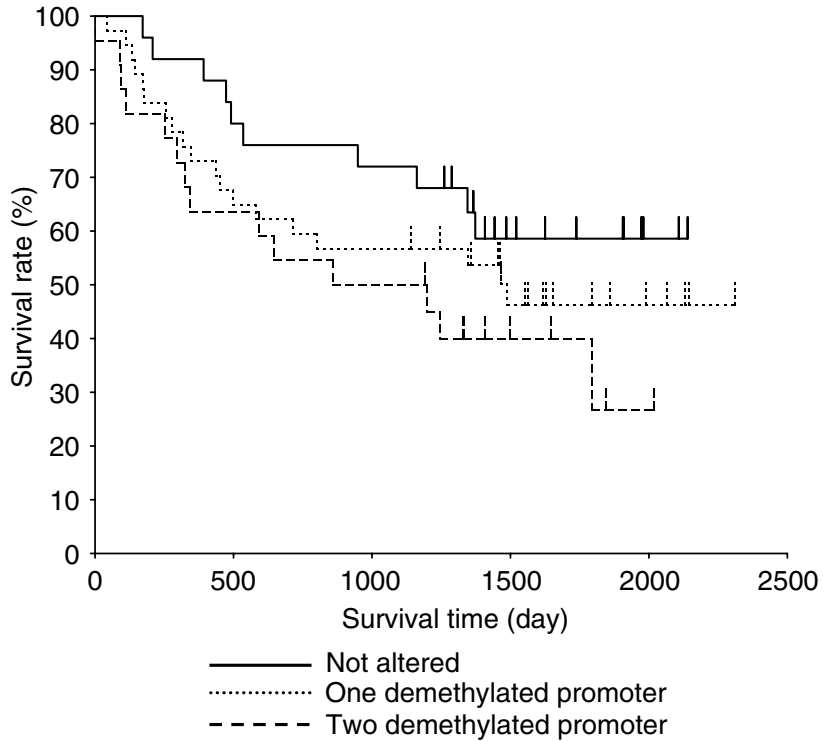

Figure 4 Methylation status and survival curve for gastric cancer patients. Patients in the 'two demethylated promoter' group tended to have a worse prognosis than patients in the 'not altered' group $(P=0.183)$. Patients in the 'one demethylated promoter' group exhibited an intermediate survival time between the two.

\section{DISCUSSION}

$M A G E-A 1$ and $-A 3$ encode tumour-specific antigens that are recognised on melanoma cells by autologous cytolytic $\mathrm{T}$ lymphocytes (Van der Bruggen et al, 1991; Boon et al, 1994). These genes are expressed in a significant proportion of tumours of various histological types, but not in normal tissues, except for male germ line cells and placenta (De Plaen et al, 1994; Takahashi et al, 1995). Demethylation of promoter $\mathrm{CpG}$ islands in MAGE genes triggers their expression in tumour cells, whereas they are not expressed in cells in which they remain methylated (De Smet et al, 1996). The function of the MAGE peptides are not known, although their tumour-specific expression is clearly of great importance for immunotherapy (Marchand et al, 1999; Nishiyama et al, 2001; Sadanaga et al, 2001). The MAGE-A1 and -A3 peptides are expressed in 67-73\% of gastric cancer cell lines (Inoue et al, 1995a; Li et al, 1996). In agreement with these data, we have demonstrated that MAGE-A1 and -A3 mRNA are expressed in 70 and $90 \%$ of gastric cancer cell lines, respectively. MAGE-A1 and $A 3$ mRNA has also been reported to be expressed in approximately $40 \%$ of primary gastric cancers (Inoue et al, 1995a, b; Li et al, 1996). However, these previous studies did not verify the methylation status of the $M A G E-A 1$ and $-A 3$ promoter $C p G$ islands. In the present study, we showed that the methylation status of the MAGE-A1 and -A3 promoters almost directly correlated with their expression status in gastric cancer cell lines.

Global DNA hypomethylation is thought to occur during the early stages of tumour development in gastric and other tissues (Goelz et al, 1985; Narayan et al, 1998; Lin et al, 2001; Bariol et al, 2003). Additionally, in pulmonary carcinogenesis, demethylation of the promoter $\mathrm{CpG}$ islands of $M A G E$ genes has been observed not only in tumours but also in the adjacent non-neoplastic lung tissues and bronchial epithelia from smokers (Jang et al, 2001). Therefore, MAGE genes may be activated prior to malignant transformation in the lung, possibly by global DNA hypomethylation (Tamura, 2002). However, we have demonstrated that MAGE gene promoters are demethylated more frequently in gastric cancers at advanced clinical stages. Furthermore, demethylation of 
$M A G E-A 1$ and $-A 3$ is quite rare in non-neoplastic gastric tissues of gastric cancer patients. In a separate study, we have confirmed that demethylation of $M A G E-A 1$ and $-A 3$ was also very rare in various organs obtained at autopsies, from various age groups (data not shown). Therefore, we hypothesise that demethylation of $M A G E$ genes occurs during progressive stages of gastric carcinogenesis, probably after global DNA hypomethylation. Promoter CpG islands of several tumour suppressor and tumour-related genes are frequently methylated in both neoplastic and nonneoplastic gastric epithelia (Tamura, 2002; Waki et al, 2002). Hypermethylation of different genes increases with age in different organs (Waki et al, 2003). These results suggest that hypermethylation of promoter $\mathrm{CpG}$ islands occurs very early in gastric carcinogenesis, in contrast to demethylation of $M A G E$ gene promoters.

Several studies have analysed MAGE gene expression Inoue et al, 1995a, b; Cravo et al, 1996; Li et al, 1996; Sadanaga et al, 2001), but none have evaluated the demethylation status of their promoters in gastric cancer. Inoue et al (1995a, b) detected MAGE expression in about $40 \%$ of primary gastric cancers, but failed to find any significant correlation between $M A G E$ expression and clinicopathological parameters (Inoue et al, 1995a,b). In the present study, demethylation of either MAGE-A1 or $-A 3$ was not significantly correlated with clinicopathological parameters, but demethylation of both genes significantly correlated with advanced clinical stage and lymph node metastasis. Furthermore, we have noticed that patients with tumours showing demethylation of both MAGE-A1 and -A3 tend to have a worse prognosis, although this difference was not statistically significant. In contrast, hypermethylation of the $h M L H 1$ gene promoter is a marker of a better prognosis (Yamamoto et al, 1999). No correlation has been observed between demethylation of the $M A G E$ genes and hypermethylation of $h M L H 1$ or $p 16$ (data not shown).

In summary, demethylation of the MAGE-A1 and $-A 3$ promoters frequently occurs during progressive stages of gastric carcinogenesis and may be associated with aggressive biological behaviour of gastric cancer.

\section{REFERENCES}

Bariol C, Suter C, Cheong K, Ku SL, Meagher A, Hawkins N, Ward R (2003) The relationship between hypomethylation and $\mathrm{CpG}$ island methylation in colorectal neoplasia. Am J Pathol 162: 1361 - 1371

Boon T, Cerottini JC, Van den Eynde B, van der Bruggen P, Van Pel A (1994) Tumor antigens recognized by T lymphocytes. Annu Rev Immnol 12: $337-365$

Brasseur F, Marchand M, Vanwijk R, Herin M, Lethe B, Chomez P, Boon T (1992) Human gene MAGE-1, which codes for a tumor-rejection antigen, is expressed by some breast tumors. Int J Cancer 52: 839-841

Chambost H, Brasseur F, Coulie P, De Plaen E, Stoppa AM, Baume D, Mannori P, Boon T, Maraninchi D, Olive D (1993) A tumor-associated antigen expression in human haematological malignancies. $\mathrm{Br} \mathrm{J}$ Cancer 84: $524-526$

Cheah MS, Wallace CD, Hoffman RM (1984) Hypomethylation of DNA in human cancer cells: a site-specific change in c-myc oncogene. J Natl Cancer Inst 73: 1057 - 1061

Choi JH, Kwon HJ, Yoon BI, Kim JH, Han SU, Joo HJ, Kim DY (2001) Expression profile of histone deacetylase 1 in gastric cancer tissues. Jpn J Cancer Res 92: 1300 - 1304

Counts JL, Goodman JI (1994) Hypomethylation of DNA: an epigenetic mechanism involved in tumor promotion. Mol Carcinog 11: 185-188

Cravo M, Pinto R, Chaves P, Gloria L, Nobre-Leitao C, Mira FC (1996) Global DNA hypomethylation occurs in the early stages of intestinal type gastric carcinoma. Gut 39: 434-438

De Plaen E, Arden K, Traversari C, Gaforio JJ, Szikora JP, De Smet C, Brasser F, Van der Bruggen P, Lethe B, Lurquin C, Brasser R, Chomez P, De Backer O, Cavenee W, Boon T (1994) Structure, chromosomal localization, and expression of 12 genes of the MAGE family. Immunogenetics 40: $360-369$

De Smet C, De Backer O, Faraoni I, Lurquni C, Brasseur F, Boon T (1996) The activation of human gene MAGE-1 in tumor cells is correlated with genome-wide demethylation. Proc Natl Acad Sci USA 93: 7149-7153

De Smet C, Lurquin C, van der Bruggen P, De Plaen E, Brasseur F, Boon T (1994) Sequence and expression pattern of the human MAGE2 gene. Immunogenetics 39: $121-129$

Eden A, Gaudet F, Waghmare A, Jaenisch R (2003) Chromosomal instability and tumors promoted by DNA hypomethylation. Science 300: 455

Gaudet F, Hodgson JG, Eden A, Jackson-Grusby L, Dausman J, Gray JW, Leonhardt H, Jaenisch R (2003) Induction of tumors in mice by genomic hypomethylation. Science 300: 489-492

Goelz SE, Vogelstein B, Hamilton SR, Feinberg AP (1985) Hypomethylation of DNA from benign and malignant human colon neoplasm. Science 228: $187-190$

Goodman JI, Watson RE (2002) Altered DNA methylation: a secondary mechanism involved in carcinogenesis. Ann Rev Pharmacol Toxicol 42: $501-525$

Gotoh K, Yatabe Y, Sugiura T, Takagi K, Ogawa M, Takahashi T, Takahashi T, Mitsudomi T (1998) Frequency of MAGE-3 gene expression in HLAA2 positive patients with non-small cell lung cancer. Lung Cancer 20: $117-125$

Inoue $\mathrm{H}$, Li J, Honda $\mathrm{M}$, Nakashima $\mathrm{H}$, Shibuta $\mathrm{K}$, Arinaga $\mathrm{S}$, Ueo $\mathrm{H}$, Mori M, Akiyoshi T (1995a) MAGE-1 mRNA expression in gastric carcinoma. Int J Cancer 64: 76-77

Inoue $\mathrm{H}$, Mori $\mathrm{M}$, Honda $\mathrm{M}$, Li J, Shibuta $\mathrm{K}$, Mimori $\mathrm{K}$, Ueo $\mathrm{H}$, Akiyoshi T (1995b) The expression of tumor-rejection antigen 'MAGE' gene in human gastric carcinoma. Gastroenterelogy 109: $1522-1525$

Jang SJ, Soria JC, Wang L, Hassan AH, Morice RC, Walsh GL, Hong WK, Mao L (2001) Activation of melanoma antigen tumor antigens occurs early in lung carcinogenesis. Cancer Res 61: 7959-7963

Jones PA, Baylin SB (2002) The fundamental role of epigenetic events in cancer. Nat Rev Genet 3: 415-429

Jones PA, Takai D (2001) The role of DNA methylation in mammalian epigenetics. Science 293: $1068-1070$

Kim MS, Kwon HJ, Lee YM, Baek JH, Jang JE, Lee SW, Moon EJ, Kim HS, Lee SK, Chung HY, Kim CW, Kim KW (2001) Histone deacetylases induce angiogenesis by negative regulation of tumor suppressor genes. Nat Med 7: 437-443

Lengauer C (2003) An unstable liaison. Science 300: $442-443$

Li J, Yang Y, Fujie T, Baba K, Ueo H, Mori M, Akiyoshi T (1996) Expression of BAGE, GAGE, and MAGE genes in human gastric carcinoma. Clin Cancer Res 2: 1619-1625

Lin CH, Hsieh SY, Sheen IS, Lee WC, Chen TC, Shyu WC, Liaw YF (2001) Genome-wide hypomethylation in hepatocellular carcinogenesis. Cancer Res 61: $4238-4243$

Lucas S, Plaen ED, Boon T (2000) MAGE-B5, MAGE-B6, MAGE-C2, and $M A G E-C 3$ : four new members of the MAGE family with tumor-specific expression. Int $J$ Cancer 87: 55-60

Marchand M, Van Baren N, Weynants P, Brichard V, Dreno B, Tessier MH, Rankin E, Parmiani G, Anenti F, Humblet Y, Bourlond A, Vanwijck R, Lienard D, Beauduin M, Dietrich PY, Russo V, Kerger J, Masucci G, Jager E, De Greve J, Atzopodien J, Brasser F, Coulie PG, Van der Bruggen P, Boon T (1999) Tumor regressions observed in patients with metastatic melanoma treated with an antigenic peptide encoded by gene MAGE-3 and presented by HLA-A1. Int J Cancer 80: $219-230$

Narayan A, Ji W, Zhang X, Marrogi A, Graff JR, Baylin SB, Ehrlich M (1998) Hypomethylation of pericentromeric DNA in breast adenocarcinomas. Int J Cancer 77: $833-838$

Nishiyama T, Tachibana M, Horiguchi Y, akamura K, Ikeda Y, Takesako K, Murai M (2001) Immunotherapy of bladder cancer using autologous dendritic calls pulsed with human lymphocyte antigen-A-24-specific MAGE-3 peptide. Clin Cancer Res 7: 23-31 
Sadanaga N, Nagashima H, Mashino K, Tahara K, Tamaguchi H, Ohta K, Fujie T, Tanaka F, Inoue H, Takesako K, Akiyoshi T, Mori M (2001) Dendritic cell vaccination with MAGE peptide is a novel therapeutic approach for gastrointestinal carcinomas. Clin Cancer Res 7: $2277-2284$

Sharrad RM, Royds JA, Rogers S, Shorthouse AJ (1992) Patterns of methylation of the c-myc gene in human colorectal cancer progression. Br J Cancer 65: 667-672

Takahashi K, Shichijo S, Noguchi M, Hirohata M, Itoh K (1995) Identification of MAGE-1 and MAGE-4 proteins in spermatogonia and primary spermatocytes of testis. Cancer Res 55: 3478-3482

Takahashi Y, Toshino I, Ohgami A, Takenoyama M, Hanagiri T, Nomoto K, Yasumoto K (1998) Expression of the melanoma antigen-encoding gene in human lung cancer. J Surg Oncol 67: 126-129

Tamura G (2002) Genetic and epigenetic alterations of tumor suppressor and tumor-related genes in gastric cancer. Histol Histopathol 17: $323-329$
Van der Bruggen P, Traversari C, Chomez P, Lurquin C, De Plaen E, Van den Eynde B, Knuth A, Boon T (1991) A gene encoding an antigen recognized by cytolytic $\mathrm{T}$ lymphocytes on a human melanoma. Science 254: $1643-1647$

Waki T, Tamura G, Sato M, Motoyama T (2003) Age-related methylation of tumor suppressor and tumor-related genes: an analysis of autopsy samples. Oncogene 22: $4128-4133$

Waki T, Tamura G, Tsuchiya T, Sato K, Nishizuka S, Motiyama T (2002) Promoter methylation status of E-cadherin, $h M L H 1$, and p16 genes in nonneoplastic gastric epithelia. Am J Pathol 161: 399-403

Weitzman SA, Lee RM, Ouellette AJ (1989) Alterations in c-abl gene methylation in cells transformed by phagocyte-generated oxidants. Biochem Biophys Res Comm 158: 24-30

Yamamoto H, Perez-Piteira J, Yoshida T, Terada M, Itoh F, Imai K, Perucho M (1999) Gastric cancer of the microsatellite mutator phenotype display characteristic genetic and clinical features. Gastroenterology 116: $1348-1357$ 